\title{
DIVERSITY MEASURES AND QUALITY OF BANKS' BOARDS: THE ITALIAN CASE
}

\author{
ROSSELLA LOCATELLI* and CRISTIANA SCHENA ${ }^{\dagger}$ \\ Università degli Studi dell'Insubria, Department of Economics \\ Via Monte Generoso, 71, 21100 Varese (Italy) \\ *rossella.locatelli@uninsubria.it \\ †cristiana.schena@uninsubria.it \\ ALESSANDRA TANDA \\ Università degli Studi di Genova \\ Department of Economics and Business \\ Via Vivaldi, 5, 16126 Genova (Italy) \\ alessandra.tanda@unige.it \\ ANDREA USELLI \\ Università degli Studi dell'Insubria, Department of Economics \\ Via Monte Generoso, 71, 21100 Varese (Italy) \\ andrea.uselli@uninsubria.it \\ Received 26 February 2018 \\ Accepted 2 October 2018 \\ Published 10 December 2018
}

\begin{abstract}
Most of the studies in corporate governance in banks and other types of firms investigate board diversity and quality separately, without considering the possible relationship between these two. To fill this gap, this study investigates through a new methodological approach the level of quality and diversity of the boards of a sample of Italian banks using a proprietary handcollected database; in addition, it examines the relationship between diversity and quality of boards to verify whether more diversity consistently relates to higher quality, in accordance with the regulatory approach.

Evidence shows that especially small and mutual banks need to improve quality and diversity, as they probably suffer from their limited attractiveness to top profile directors. Moreover, on analyzing interrelations we find evidence of a positive association between board diversity and quality. In particular, financial skills and experience of directors improve the qualitative level of banking boards.
\end{abstract}

Keywords: Corporate governance; bank governance; board composition; board diversity and quality; bank regulation.

This is an Open Access article published by World Scientific Publishing Company. It is distributed under the terms of the Creative Commons Attribution 4.0 (CC-BY) License. Further distribution of this work is permitted, provided the original work is properly cited. 


\section{R. Locatelli et al.}

\section{Introduction}

Corporate governance is a well-studied topic and the theoretical and empirical literature has provided a wide number of contributions. Nevertheless, studies and theories are often independent of the firms' industrial sector and they are not fully applicable to the banking industry (John et al. 2016, Mehran et al. 2011), ${ }^{\text {a }}$ where studies are less numerous and mostly focused on listed banks. Within the broad set of corporate governance studies, board composition has been investigated mainly in terms of demographic diversity of board members or, in a few studies, in terms of the impact of the quality of governance on performance, value creation or risk-taking. This stream of literature is wide and has yielded mixed results (de Haan \& Vlahu 2016, John et al. 2016, Yermack 2006). Diversity and quality have been usually defined according to individual profiles or attributes of board members, without taking jointly into account these two different aspects.

To fill this gap, this study investigates the level of quality and diversity of the boards of a highly representative sample of listed and unlisted Italian banks; in addition, it examines the relationship between diversity and quality of boards. We focus on the Italian case because the country legislation on banking boards' structure has historically been very heedful on the issue (Bank of Italy 2006, 2008, Frigeni 2016) and it has undergone important changes, particularly regarding composition and functioning of the board ${ }^{\mathrm{b}}$ in line with the emerging European framework ${ }^{\mathrm{c}}$

\footnotetext{
a Banks are "special" because of their specific regulation on governance (Armour et al. 2016, Hopt 2013) and because they are highly leveraged and depend on depositors for their funding (John et al. 2016, Laeven 2013). Their activity is complex and this complexity is mirrored in their balance sheets' "opaqueness" (de Haan \& Vlahu 2016, John et al. 2016, Levine 2004, Mehran et al. 2011). As Srivastav \& Hagendorff (2016) state, banks' boards are "the apex of the internal governance system. Boards hold overall responsibility for providing oversight into the monitoring of bank management, setting executive compensation contracts, and implementing an effective system of risk governance" and also by "monitoring and advising senior bank executives". The capability of board members to perform these tasks influences decisions and shareholders' value creation (Masulis et al. 2012).

${ }^{b}$ For a more complete overview of the governance in the Italian banking system, see Caselli (2010), Carretta \& Schwizer (2015) and Schwizer (2017).

${ }^{\mathrm{c}}$ The Basel Committee, in its document released in July 2015 titled "Guidelines - Corporate Governance Principles for Banks", detailed more closely qualifications that are useful to identify and verify requirements for each board member and the board as a whole. These items have a particular relevance: " 48 . The board should be comprised of individuals with a balance of skills, diversity and expertize, who collectively possess the necessary qualifications commensurate with the size, complexity and risk profile of the bank. 49. In assessing the collective suitability of the board, the following should be taken into account:
}

- board members should have a range of knowledge and experience in relevant areas and have varied backgrounds to promote diversity of views. Relevant areas of competence may include, but are not limited to capital markets, financial analysis, financial stability issues, financial reporting, information technology, strategic planning, risk management, compensation, regulation, corporate governance and management skills;

- the board collectively should have a reasonable understanding of local, regional and, if appropriate, global economic and market forces and of the legal and regulatory environment. International experience, where relevant, should also be considered; and

- individual board members' attitude should facilitate communication, collaboration and critical debate in the decision-making process." (Basel Committee for Banking Supervision, 2015.) 
(BCBS 2015, EBA 2016, ESMA-EBA 2016, ECB 2017, OECD 2015). Additionally, despite the regulator's attention to corporate governance issues, Italian banks have also experienced inefficient governance (Jassaud 2014).

In detail, we contribute to the existing literature on bank corporate governance by answering the following research questions:

- RQ1: What is the level of quality of the board of directors in Italian banks?

- RQ2: What is the level of diversity in Italian banks boards, measured consistently with the regulatory perspective?

Answering the two questions above, we also advance the methodological approach by employing novel measures for quality and diversity. Board quality is computed as the competence profile of directors, including educational background and experience. Diversity is investigated as a set of comprehensive measures on the various diversity profiles (not only demographic but also educational level and experience) using the Blau Index, the Jaccard Index and the Total Heterogeneity Score (THS). To our knowledge, this is the first study to analyze diversity in boards applying different indicators referring to the full board and considering together different diversity features.

— RQ3: Does diversity contribute to the overall quality of the bank's board? Is it possible for a bank to have higher diversity and — at the same time — better and more qualified boards?

In the study, we take into account the interdependency between diversity and quality (Hardwick et al. 2011) which most studies ignore; moreover, consistently with de Haan \& Vlahu (2016), we expand research on board members characteristics. Results highlight that higher diversity is consistent with higher quality.

The paper is organized as follows: the second section reviews the most relevant theoretical and empirical literature and presents the hypothesis tested; the third illustrates the methodology; the fourth describes the sample; the fifth discusses the results; and the last one concludes.

\section{Literature Review}

Board composition, expertize, and diversity in firms have been widely investigated by a vast literature on corporate governance (de Haan \& Vlahu 2016). The characteristics of boards are interpreted as determinants of the effectiveness of boards and the capability of decision-making (de Haan \& Vlahu 2016, Forbes \& Milliken 1999). More qualified boards should be able to better monitor managers in banks (Fama \& Jensen 1983) and reduce asymmetries of information (Adams et al. 2010, Harris \& Raviv 2006, Faleye et al. 2017, von Meyerinck et al. 2016). Managers, in their turn, are believed to need more board advice in complex firms (Klein 1998, Coles et al. 2008). As for diversity, the psychological literature also claims that 


\section{R. Locatelli et al.}

homogeneous members in a group yield to "groupthink" are an obstacle for innovative thinking (Coles et al. 2015, Klein 1998).

Most studies investigate these aspects in isolation as individual characteristics and not from the board perspective. This appears surprising, almost in banking literature, as the latter is the perspective taken in the years by the regulatory bodies.

Banking regulation introduces a definition of board heterogeneity that is more complex than the one used by most of the studies: diversity is not simply defined as the percentage of some specific types of directors (female, independent, ${ }^{\mathrm{d}}$ international, etc.), but refers also to the board as a group; diversity is not only referred to as "demographic" diversity, but also education and background. The economic literature, to the best of our knowledge, fails to look at both competence and diversity contemporaneously as a prerequisite of good governance and to refer to a more complex definition of diversity.

A large part of literature has studied corporate governance characteristics summarized by the directors' features, linking them to economic performance, value creation or risk-taking (for a review, see de Haan \& Vlahu 2016, see also the discussion in Berger et al. 2016). Instead, very few studies examined the impact of board composition on board efficiency as the capability of making good decisions (Forbes \& Milliken 1999, Pugliese et al. 2009); these are mainly performed in the field of organizational studies and mostly do not focus on banks (or other regulated industries). In general, these studies find a positive relation between heterogeneous boards and board efficiency. A relevant stream of law studies also deals with corporate governance and board members characteristics in banks from a regulatory point of view without testing relationships or causality hypotheses (among these, see Hopt 2013, Macey \& O'Hara 2003, Mülbert 2009) and most of these results are not all fully applicable to banks, because of the different governance mechanisms and the different nature of business (John et al. 2016).

\subsection{Quality of boards in the literature}

The few and recent studies on the quality of boards of directors show that a more qualified and competent board of directors is better able to "engage in good dialogue to ensure that the company's actions and decisions take into account the wide range of factors that could affect stakeholders" (Mehran et al. 2011). Managerial studies on board quality focus in particular on the presence of financial expertize and its relation with economic performance or risk-taking, finding mixed results. In general a positive

\footnotetext{
${ }^{\mathrm{d}}$ Independence of directors is sometimes interpreted as diversity in a broad sense. This paper does not test for independence of directors, but it is appropriate to recall that much literature is devoted to this issue linked to economic performance. Studies find controversial results (Agrawal \& Knoeber 1996, Baysinger \& Butler 1985, Bhagat \& Black 2002, Brickley et al. 1994, Coles et al. 2008, Hermalin \& Weisbach 1991, Weisbach 1988, Yermack 1996, Cornett et al. 2009 and Mishra \& Nielsen 2000 for the banking industry). The reader might refer to de Haan \& Vlahu (2016) and John et al. (2016) for a more comprehensive review of the issue.
} 
effect on performance or risk-taking seems to prevail (among others, see Aebi et al. 2012, Erkens et al. 2012, Mehran et al. 2011, Minton et al. 2014, Srivastav \& Hagendorff 2016; for a review, see de Haan \& Vlahu 2016 and John et al. 2016), but the result crucially depends on the measure chosen as a proxy for quality (John et al. 2016).

The underlying assumption is that the level of theoretical competence and the qualification of individual experience may enrich the board set of skills and result in more effective board functioning (Faleye et al. 2017). The higher the competence in a board, the greater is the expected influence over management (especially the CEO) in terms of advisory role, control and planning (Adams \& Ferreira 2009, Fama \& Jensen 1983, Faleye et al. 2017, Harris \& Raviv 2006, Jensen 1993, Klein 1998).

Because of these mixed results and consistently with the regulatory definition of competence, the literature suggests to include other variables to proxy for quality of board members (John et al. 2016) and that boards and directors are "not onedimensional" (Adams et al. 2018). In line with this approach, this study employs a comprehensive measure of quality derived from educational background, expertize and experience, in coherence with the few studies that verify the overall level of board quality by evaluating the directors' curricula (Adams et al. 2018, Hau \& Thum 2009, Cuñat \& Garicano 2010).

\subsection{Board diversity in the literature}

The consolidated literature on diversity provides mixed results (see de Haan \& Vlahu 2016 for a review). Diversity is considered as a prerequisite of good governance, especially in banks (de Haan \& Vlahu 2016, Srivastav \& Hagendorff 2016).

The economic literature on diversity focuses on the impact of diversity (usually gender ${ }^{\mathrm{f}}$ and racial diversity or the presence of specific types of directors, as politicians or politically appointed members or academics) on measures of performance or risktaking and finds controversial results (see, for instance, Bear et al. 2010, Beltratti \& Stulz 2012, Burke 1997, Ferreira 2010, Miller \& Del Carmen Triana 2009,

\footnotetext{
e Another variable often taken as a proxy of the overall efficiency of a board's functioning, is time dedication, i.e. the "theoretical" amount of time that a director can allocate to his/her duties as a board member. The regulation states that time dedication has to be "adequate," and some banks have already established specific internal policies. The impact of time dedication on board functioning is well explored in literature but yields mixed results. On the one hand, the busier board members are, the lower their time dedication is; as a consequence, inefficiencies and board malfunctioning can arise (Lipton \& Lorsch 1992, Shalley 1991). On the other hand, if directors are busy, it probably means that they have greater experience and/or expertize and might contribute positively to the board's effectiveness (Harris \& Shimizu 2004). Time dedication is not necessarily considered a proxy for the level of skill and of potential contribution to the quality of board performance and because of these reasons, we do not focus on the variable. Additionally, this is a very hard measure to trace correctly given that information on curricula vitae (CVs) are provided voluntary, with no standards especially for small unlisted banks. As final consideration, board members who have now a high time dedication may have accumulated important and long-lasting expertize in the past and then focused on few positions.

${ }^{\mathrm{f}}$ For a review on gender diversity, see Del Prete \& Stefani (2015).
} 


\section{R. Locatelli et al.}

Pathan 2009, Arnaboldi et al. 2018). ${ }^{g}$ On the issue, Bøhren \& Strøm (2010) highlight the lack of relationship between board diversity (as just defined) and economic performance $^{\mathrm{h}}$ : the authors claim that no "convincing economic reason" justifies the imposition by law of a minimum level of representativeness of certain "profiles". This statement appears consistent with the regulatory approach: diversity is a basic condition to ensure good governance and must be defined in a more complex way than the percentage of types of directors. Diversity can be the key to effective managerial decisions, a richness in the group's dynamics to enhance creativity and the capacity for innovation and, more generally, to increase the operating efficiency of the board, taking nonobvious solutions (Richard 2000, Shergill 2001, Van der Walt et al. 2006, on banks see Bantel \& Jackson 1989). Diversity in a board as a group can be a way to prevent group thinking or herd behavior, which are typical examples of failures in governance (Faleye et al. 2017). But this can also be an obstacle and a source of conflict (Coles et al. 2015, Forbes \& Milliken 1999).

Solanas et al. (2012) suggest that different interpretations of diversity and connected measures have different power in explaining diversity in a group. While some measures might be more appropriate to investigate gender or demographic aspects one at a time, it might be more difficult to simultaneously consider all the aspects in a synthetic measure of diversity. It might be that two boards are diverse in consequence of different percentage of women, foreign or independent members, but this does not say anything about the interaction between independent and executive, foreign and domestic, women or men in defining a diversified board.

\subsection{Quality and diversity as features of the board of directors effectiveness}

It seems clear that the different dimensions of board composition should be evaluated together and interdependently to fully appreciate the governance mechanism (Adams et al. 2010, Hardwick et al. 2011). Boards are nevertheless a sort of "black box" (Payne et al. 2009): it is difficult to measure a board's functioning from the outside and, therefore, it is difficult to search for indicators to appreciate the efficiency and effectiveness of a board's functioning. In addition, also human, moral and behavioral characteristics affect board functioning (Sonnenfeld 2002), but these dimensions are hard to identify and measure. For these reasons, we focus on a measure of quality, rather than a measure of board effectiveness. Although we agree

\footnotetext{
g Most of the contributions using an economic approach link board characteristics to performance at the same time, but do not consider the time lag required for a new board to get in touch with all the determinants of bank profitability or the time necessary to produce effects on performance. Nevertheless, this stream of study lies outside the scope of this paper (we do not test for the impact of diversity on performance or risk-taking). For a review, see de Haan \& Vlahu (2016), Locatelli et al. (2018).

${ }^{\mathrm{h}}$ It is just the case to recall the contribution by Adams et al. (2010), who argue that different firms (with different characteristics) choose different governance solutions that yield different performance levels: the choice of governance structures can be considered endogenous, and empirical literature commonly fails to take this into account by assuming that some predetermined models hold across all companies.
} 
with Faleye et al. (2017) in assuming that a high qualitative level of the board's members can contribute to increasing board effectiveness (Faleye et al. 2017), we do not test for this as we cannot measure effectiveness directly and we focus our attention on the quality of the board.

Van der Walt \& Ingley (2003) also observe that the heterogeneity of a board is not sufficient to ensure good governance if it is not linked to qualified individuals. The board's "value added" is a sort of "social capital" available for the firm. Board efficiency is strictly related to the qualification of its members within the mix of profiles. As a consequence, a bank should choose its optimal board trying to balance the need for qualified and expert directors and the need to ensure effective decisionmaking through the presence of different profiles.

Following this approach, we test the link between quality and diversity as the basis for good governance (Adams et al. 2010, de Haan \& Vlahu 2016, Van der Walt \& Ingley 2003). We expect to find a positive correlation between diversity and quality of the board.

\section{Hypothesis 1. Higher diversity yields a higher quality.}

Additionally, we expect "demographic" diversity to also impact quality: if banks choose their board members to have a high-quality board of directors, we expect they will include only qualified women, international directors and members of different age. We expect to find a positive coefficient for the three characteristics.

Hypothesis 2. A board with different aged directors has a higher quality. Hypothesis 3. A board with higher gender representation has a higher quality. Hypothesis 4. A board with more international components has a higher quality.

\section{The Methodology}

\subsection{Measures of quality}

To evaluate quality, we follow hence Minton et al. (2014) and Payne et al. (2009) and compute a "Quality score" on education, background and on "practical" competence, derived from the level, mix, and type of experience reported in the curriculum vitae. Individual skills contribute to the level of expertize of each member of board.

The score for each board member varies from 0 to 30 (see Table 1) and the average of each score for the individual members represents the quality score of the board.

We record the level of the degree for each director, as well as the area in which the degree is taken. A different score (see Table 1) is assigned to each degree type to summarize the level of education as a proxy for education and background of each director.

Expertize is evaluated separately for past experiences in the board of directors and for managerial positions. For both, past experience is measured as "high," 


\section{R. Locatelli et al.}

Table 1. Details of scores for education and background and "practical" competencies of board members used to calculate the "Quality score".

\begin{tabular}{|c|c|c|c|c|c|}
\hline Education & Score & Board experience & Score & Managerial experience & Score \\
\hline No degree & 0 & 1 or 2 positions $\Rightarrow$ low & 3 & 1 or 2 positions $\Rightarrow$ low & 3 \\
\hline Degree & 3 & $3-5$ positions $\Rightarrow$ medium & 5 & $3-5$ positions $\Rightarrow$ medium & 5 \\
\hline Economics/Business & 1 & Over 5 positions $\Rightarrow$ high & 7 & Over 5 positions $\Rightarrow$ high & 7 \\
\hline Law & 1 & & & & \\
\hline Master & 2 & $\begin{array}{l}\text { Financial experience } \\
\text { premium }\end{array}$ & 1 & $\begin{array}{l}\text { Financial experience } \\
\text { premium }\end{array}$ & 1 \\
\hline Economics/Business & 1 & $\begin{array}{l}\text { Recent (last } 5 \text { years) } \\
\text { experience premium }\end{array}$ & 1 & $\begin{array}{l}\text { Recent (last } 5 \text { years) } \\
\text { experience premium }\end{array}$ & 1 \\
\hline Law & 1 & $\begin{array}{l}\text { International experience } \\
\text { premium }\end{array}$ & 1 & $\begin{array}{l}\text { International experience } \\
\text { premium }\end{array}$ & 1 \\
\hline Doctorate/Ph.D. & 2 & & & & \\
\hline Economics/Business & 1 & & & & \\
\hline Law & 1 & & & & \\
\hline Maximum score & 10 & Maximum score & 10 & Maximum score & 10 \\
\hline
\end{tabular}

"medium" or "low," depending on the number of board positions currently or previously held (Table 1).

Moreover "premia" (with an additional score) are assigned if board and/or managerial experience have been acquired in banks and financial intermediaries ("financial" premium), at an international level or within a multinational enterprise ("international" premium), and achieved over the last five years ("recent" premium) (Table 1). These premia reflect the idea that the more qualified and specialized a board member is, the more he/she contributes to the board's functioning (Faleye et al. 2017).

\subsection{Measures of diversity}

Taking the perspective introduced by Harrison \& Klein (2007), this study analyzes diversity as "separation" and "variety". ${ }^{i}$ Departing from previous literature, three different measures of diversity are employed to evaluate the presence of specific heterogeneity features among members (demographic, educational background, board and managerial experience, financial skills), to provide a comprehensive picture of diversity in boards and test the consistency of these measures among similar banks.

\footnotetext{
iIn fact, according to Harrison \& Klein (2007), diversity can be interpreted as "disparity" when a member of a group has skills or competencies that the others do not have, and this makes him/her dominant in the group. This measure is particularly suitable when analyzing the role of the CEO or the chairman of a board. Diversity can also be interpreted as "separation" when board members differ in given features, such as independence or executive roles. Finally, a notion of diversity as "variety" can be mentioned, when heterogeneous individuals, according to multiple perspectives, are mixed together.
} 
Table 2. Description of different Blau Indexes computed for each feature.

\begin{tabular}{ll}
\hline Diversity feature & \multicolumn{1}{c}{ Category } \\
\hline Education (Blau-e) & Postgraduate degree \\
& Degree in economics/business \\
& Degree in law \\
& Degree in political science \\
& Degree in engineering/quants \\
& Degree in other areas \\
& No degree \\
& High (more than 5 positions) \\
& Medium (between 3 and 5 positions) \\
& Low (2 positions or less) \\
Board experience (Blau-b) & High (more than 5 positions) \\
& Medium (between 3 and 5 positions) \\
Managerial experience (Blau-m) & Low (2 positions or less) \\
& No financial experience \\
& Financial experience in boards \\
& Managerial financial experience \\
Financial experience (Blau-f) & Both \\
\hline
\end{tabular}

The first measure we employ is the Blau Index (Blau 1977, Campbell \& MínguezVera 2008, Solanas et al. 2012), which allows evaluating the presence of a species or category in a group. It is a widely used indicator in the governance literature - but also in other research fields - to measure diversity as variety.

The Blau Index is a concentration index measured as $B=1-\sum_{i=1}^{k} p_{i}^{2}$, where $p$ is the proportion of members of a group in a given category, and $k$ the total number of categories. It varies between 0 and $(k-1) / k$; when $\mathrm{B}$ is equal to 0 , this implies maximum concentration (or minimum diversity); when $\mathrm{B}$ is equal to its maximum value $(k-1) / k$, it means there is maximum variety (or diversity). ${ }^{\mathrm{j}}$ To compare the index across variables, we employ a standardized version that varies from 1 to 0 , obtained by dividing B by its maximum.

For each of the features analyzed with reference to education and experience, categories are individuated, and each board member is assigned to a single category in each feature (see Table 2).

The second measure of diversity is the Jaccard Index (Jaccard 1901), which is a distance measure that can synthesize diversity for various characteristics. The index was first applied in the natural sciences to study diversity in eco-systems (see Chao et al. 2005), while it is less used in social sciences (among others, see Nobi et al. 2014 and Tsai \& Chiu 2004). Unlike the Blau index, the Jaccard index expresses the idea of diversity as separation defined by Harrison \& Klein (2007), which appears

$\mathrm{j}$ Actually, the Blau Index can also be interpreted as B=1-HHI, where HHI is the Herfindahl Index, a wellknown index to measure concentration. 


\section{R. Locatelli et al.}

Table 3. Jaccard Index categories.

\begin{tabular}{ll}
\hline Variables & \\
\hline Gender & Female \\
& Male \\
International & Yes \\
& No \\
Age range & Under 40 \\
& $40-49$ \\
& $50-59$ \\
& 60 or over \\
& Postgraduate degree \\
Education & Degree in economics/business \\
& Degree in law \\
& Degree in political science \\
& Degree in engineering/quants \\
& Degree in other areas \\
& No degree \\
& Yes \\
& No \\
Financial competence in education & High (more than 5 positions) \\
Board experience & Medium (between 3 and 5 positions) \\
& Low (2 positions or less) \\
& High (more than 5 positions) \\
& Medium (between 3 and 5 positions) \\
Managerial experience & Low (2 positions or less) \\
&
\end{tabular}

consistent with the regulatory approach because it underscores synthetically diversity in a group.

To build the Jaccard Index, the database has been translated into a binary database in which each characteristic or attribute (e.g. age range, gender, nationality $^{\mathrm{k}}$ ) is present (1) or not (0) for each board member (see Table 3). According to the literature, the index is calculated for each couple of board members within a board as $J(i, j)=\frac{a}{a+b+c}$, where:

$a=$ totals number of attributes where both board members $i$ and $j$ have 1 ;

$b=$ total number of attributes where board member $i$ has 1 and board member $j$ has 0 ; and

$c=$ total number of attributes where board member $i$ has 0 and board member $j$ has 1 .

The Jaccard index expresses the ratio between the number of occurrences of attributes 1-1 for each couple for a given qualitative element and the number of observations, without taking into account the occurrences with $0-0$ for each couple. It varies from 1 (maximum similarity) to 0 (maximum diversity).

\footnotetext{
${ }^{\mathrm{k}}$ To provide an example, a foreign female director aged 55 would have a 1 in the variables age range "50-59", female and international.
} 
When the index is applied to each board, a $[n, n]$ symmetric matrix is obtained, where $n$ is the number of board members. On the main diagonal, there are only 1 as each board member is equal to him/herself. The remaining cells of the matrix contain the results of the ratios $J(i, j)$ for any pair of board members $i$ and $j$, with $i \neq j$. To synthesize the matrix, we take the average of the elements in the lower triangle $(J(i, j))$ but the " $1 \mathrm{~s}$ " in the main diagonal.

The third measure of diversity we employ is the THS, according to Anderson et al. (2011). The authors divide each quality profile of the board members of a sample of nonfinancial firms into quartiles and give a score to each board according to the quartile it belongs to, as follows: 1 point if in the I quartile (minimum heterogeneity); 4 points if in the IV quartile (maximum heterogeneity). The sum of the scores gives the THS. Nine different heterogeneity profiles are considered, ${ }^{1}$ yielding a THS ranging from 9 to 36 . No board reaches the maximum score (equal to 36): the scores range from a minimum of 16 to a maximum of 28 , with a mean of 21.7 and a median of 21 .

\subsection{The relationship between diversity and quality}

Although as said, diversity should contribute to the effectiveness of the board and, as an extension to its quality, the existing empirical literature does not support us in developing a hypothesis on the specific link between diversity and the qualitative level (competence) of a board: diversity might be low if all the directors are similar, either all good and competent or all low skilled and incompetent. Both these scenarios have flaws: of course, noncompetent directors are not suitable to run a company because they are not credible to the management and unable to monitor and advise it (Machold et al. 2011). This might yield to capture by the management and leadership of the president or the CEO. At the same time, if all the directors are very competent, but similar in terms of age, experience, expertize and area of studies, group thinking might yield inefficient decisions that lack creativity and are too mainstream (see the literature cited by Faleye et al. 2017).

In this study, we test the relation between diversity and quality, taking the perspective of a bank that needs to comply with both regulatory requirements simultaneously. Among others, the possible questions are as follows. Can a very diverse board also have a high quality? Introducing diversity (in the sense of different age, gender, international experience, education or board and managerial background) equals lowering the average quality of boards? For instance, does quality decrease because younger (less experienced) directors are included in the board?

\footnotetext{
${ }^{1}$ The heterogeneity profile considered are (1) age (coefficient of variation); (2) financial skills as education and background competencies (\% of administrators with degrees or post-graduate degrees in economics/ business); (3) Blau-e (educational profile); (4) gender (\% of women); (5) board experience (coefficient of variation); (6) managerial experience (coefficient of variation); (7) internationalization_1 (\% of total foreign administrators); (8) internationalization_2 (\% of directors with international experience); (9) financial skills as "practical" competencies (\% of administrators with experience on international markets or in foreign countries).
} 


\section{R. Locatelli et al.}

We expect boards diversity heterogeneity and quality to be positively related: a higher diversity score should be consistent with a higher quality if banks choose different member profiles that bring value to the board as a whole in terms of competence and background and not only for policy compliance.

The model we test is the following:

$$
\text { quality }_{j}=\alpha+\beta_{1} \mathrm{DIV}_{j}+\beta_{2} X_{j}+\beta_{3} \text { Bdsize }_{j}+\beta_{4} \mathrm{Bksize}_{j}+\varepsilon_{j},
$$

where:

— quality $_{j}$ is the quality score of the board $j$ (dependent variable);

$-\mathrm{DIV}_{j}$ is the set of diversity measures presented in the previous section, that are Blau Indexes, Jaccard Index and THS (independent variables);

$-X_{j}$ is a set of demographic diversity of board $j$, including the coefficient of variation of age (cv age), gender and international (other independent variables) ${ }^{\mathrm{m}}$;

- Bdsize $_{j}$ is the natural logarithm of the board size, in terms of number of directors (control variable);

- Bksize $_{j}$ is the natural logarithm of the bank size, in terms of total assets as at the end of 2014 (control variable);

$-\alpha$ and $\beta$ s are the coefficients, and $\varepsilon$ is the error term.

Regressions are performed using a Poisson regression that allows the dependent variable (quality) to be only zero or positive. This distribution imposes that the mean and the variance are equal. According to descriptive statistics, the variance of the variable quality is slightly higher than the mean (the mean is 11.197 while the variance is 11.978). Hence, to control for the suitability of the Poisson model, we test the dependent variable distribution for over-dispersion and we cannot reject the hypothesis of equal dispersion. Additionally, to correct for possible underestimation of standard errors, regressions are made with robust standard errors. ${ }^{\text {n }}$

To focus on the role of diversity, but also to control for financial skills in conditioning the quality level of banks' boards, we test an additional version of the previous model, explained by Eq. (3.2):

$$
\text { quality }_{j}=\alpha+\beta_{1} \mathrm{DIV}_{j}+\beta_{2} \mathrm{FE}_{j}+\beta_{3} \mathrm{Bdsize}_{j}+\beta_{4} \mathrm{Bksize}_{j}+\varepsilon_{j},
$$

where:

— quality ${ }_{j}, \mathrm{DIV}_{j}, \mathrm{Bdsize}_{j}, \mathrm{Bksize}_{j}, \alpha, \beta s$ and $\varepsilon$ are the same as in Eq. (3.1);

$-\mathrm{FE}_{j}$ is the percentage of board members with financial expertize.

\footnotetext{
${ }^{\mathrm{m}}$ In this way we also consider other diversity features of the bank's board, where: (1) "cv age" is the coefficient of variation of age, in years; (2) "gender" is the number of female directors relative to the board size; (3) "international" is the number of foreign directors (nonItalian) relative to the board size.

${ }^{\mathrm{n}}$ In additional robustness checks omitted, we also test the model using a negative binomial distribution and results remain similar in most of the cases. Nevertheless, results for over-dispersion confirm that the Poisson model is better equipped to deal with our data.
} 


\section{Sample and Data Collection}

The analysis is based on a proprietary hand-collected database containing information on 700 directors of 58 boards of the 54 main Italian banks by total assets as of December 2014 (Table 4). For each director, we collected demographic information and details on education and expertize from the CVs available on the banks' websites, updated at the end of 2015. The information has been verified and, when necessary, integrated with that derived from the reports on corporate governance and other documents publicly available on the web.

According to Orbis database, the sample represents $86 \%$ of the total assets of the Italian banking system. In the sample there are 5 major banks (i.e. total assets exceeding $€ 100$ billion), 10 large (total assets between $€ 30$ and 100 billion), 30 medium (total assets between $€ 3.5$ and 30 billion) and 9 small banks (total assets between $€ 1$ and 3.5 billion) (Table 4 ).

Within the sample, 50 banks have an Italian traditional governance model (with a board of directors and a separate audit committee). The other four banks adopt a two-tier model (management board and supervisory board); these are 2 major, 1 large and 1 medium banks. Banks with the two-tier model are larger in terms of total assets, with average total assets at the end 2014 of $€ 209,846$ million, while the banks adopting the traditional governance model have an average of around $€ 40$ billion (Table 5). Seventeen banks are listed, while the remaining 37 are not. Of the listed ones, 3 have a two-tier model. As it is reasonable, listed banks are the largest, although there is high variation within the sample.

Besides, 33 banks are limited companies, 11 are cooperative banks and 10 are mutual banks (Table 4). Mutual banks are the smallest, cooperative banks follow with an average total assets of around $€ 39$ billion and similar median, while limited

Table 4. Sample composition.

\begin{tabular}{lcc}
\hline Sample of banks & Number of banks & Number of boards \\
\hline Banks & 54 & 58 \\
Governance system & 50 & 50 \\
Traditional governance system & 4 & 8 \\
Two tier governance system & 17 & 20 \\
of which: listed & & \\
Size (classification criteria by the Bank of Italy) & 5 & 7 \\
major (total assets exceeding $€ 100$ billion) & 10 & 11 \\
large (total assets between $€ 30$ and 100 billion) & 30 & 31 \\
medium (total assets between $€ 3.5$ and 30 billion) & 9 & 9 \\
small (total assets between $€ 1$ and 3.5 billion) & & 36 \\
Legal form & 33 & 12 \\
Limited company banks & 11 & 10 \\
Cooperative banks & 10 & \\
Mutual banks & & \\
\hline
\end{tabular}


Table 5. Descriptive statistics on total assets (€mn., 2014).

\begin{tabular}{lrrrrrr}
\hline Sample of banks & $\begin{array}{c}\text { Number } \\
\text { of banks }\end{array}$ & Mean & Median Std. Dev. & Min & Max \\
& & & & & & \\
\hline Full sample & 54 & 52,015 & 12,385 & 141,389 & 2,081 & 844,217 \\
Governance model & & & & & & \\
Traditional governance model & 50 & 39,388 & 11,444 & 119,371 & 2,081 & 844,217 \\
Two tier governance model & 4 & 209,846 & 85,029 & 254,663 & 22,897 & 646,427 \\
Listed & 17 & 133,762 & 38,310 & 230,633 & 6,140 & 844,217 \\
Unlisted & 37 & 14,455 & 9,236 & 15,973 & 2,081 & 80,330 \\
Dimensional criteria & & & & & & \\
major (total assets exceeding $€ 100$ billion) & 5 & 383,791 & 183,444 & 302,564 & 121,787 & 844,217 \\
large (total assets between $€ 30$ and 100 billion) & 10 & 48,517 & 47,373 & 13,429 & 34,794 & 80,330 \\
medium (total assets between $€ 3.5$ and 30 billion) & 30 & 12,653 & 10,547 & 6,274 & 5,201 & 28,814 \\
small (total assets between $€ 1$ and 3.5 billion) & 9 & 2,787 & 2,770 & 355 & 2,081 & 3,281 \\
Legal form & & & & & & \\
Limited company banks & 10 & 70,769 & 12,564 & $1,76,890$ & 2,081 & 844,217 \\
Cooperative banks & 11 & 39,048 & 35,619 & 31,223 & 6,256 & 123,082 \\
Mutual banks & 33 & 4,392 & 2,983 & 2,696 & 2,505 & 10,528 \\
\hline
\end{tabular}

companies have a higher average (more than €70 billion), a smaller median (around $€ 13$ billion), showing a high variation in the group in terms of size (Table 5).

\section{Results}

\subsection{Quality}

Table 6 provides descriptive statistics on the full sample of directors, including demographic profiles, education, and experience. Banks' boards in the sample seem quite different, with reference to board composition and the quantitative and qualitative profiles. ${ }^{\circ}$ The average size of boards (12.07) is in line with regulatory provisions that came into force in $2017 .^{\mathrm{p}}$

Table 6 also shows that foreign and female directors are very few in number and, for several banks, they are completely absent. About $71 \%$ of board members have a degree, while the percentage of directors with financial competence or experience in

\footnotetext{
${ }^{\circ}$ Given the high heterogeneity among boards, we performed an additional statistical analysis to evaluate if banks' characteristics have a relevance in determining boards' quality and diversity. The analysis is performed through a Principal Component Analysis (PCA), and results confirm that all identified profiles contribute, almost equally, to the overall score and to the understanding of differences among boards (for details, see Appendix). Thus, we can conclude that all these profiles are important and must be consistent together to appreciate the quality and skills of board members, as required by regulation.

p With regard to quantitative requirements, the provisions of the Bank of Italy (2015) set a maximum number of board members equal to 15 (or 19 in case of one-tier model and 22 in case of two tier model). The Authority concludes that a too large board may reduce its effectiveness, as well as the incentive - per each director - to take any action to carry out its tasks. On the other side, it may hinder the functionality and decision making of the board. See Dalton et al. (1999) for a review on the effects of the size of the board on financial performance.
} 
Table 6. Descriptive statistics on boards.

\begin{tabular}{|c|c|c|c|c|c|c|c|}
\hline Sample of banks (54) & Measure & $\begin{array}{l}\text { Number of } \\
\text { observations }\end{array}$ & Mean & Median & $\begin{array}{l}\text { Std. } \\
\text { Dev. }\end{array}$ & Min & Max \\
\hline Board members & number & 700 & & & & & \\
\hline $\begin{array}{l}\text { Banks with traditional } \\
\text { governance model }\end{array}$ & number & 602 & & & & & \\
\hline $\begin{array}{l}\text { Banks with two tier } \\
\text { governance model }\end{array}$ & number & 98 & & & & & \\
\hline \multicolumn{8}{|l|}{ Board } \\
\hline Board size & number & 58 & 12.07 & 11.50 & 3.93 & 5 & 24 \\
\hline $\begin{array}{l}\text { Board size (traditional } \\
\text { governance model) }\end{array}$ & number & 50 & 12.04 & 12.00 & 3.41 & 6 & 24 \\
\hline $\begin{array}{l}\text { Board size (two-tier } \\
\text { governance model) }\end{array}$ & number & 8 & 12.25 & 8.50 & 6.24 & 5 & 23 \\
\hline \multicolumn{8}{|l|}{ Demographic profiles } \\
\hline Age & years & & 61.1 & 61.0 & 10.1 & 27 & 86 \\
\hline Foreign directors & $\%$ & & $6.0 \%$ & $0.0 \%$ & $12.4 \%$ & $0.0 \%$ & $50.0 \%$ \\
\hline Female directors & $\%$ & & $15.1 \%$ & $16.0 \%$ & $10.8 \%$ & $0.0 \%$ & $50.0 \%$ \\
\hline \multicolumn{8}{|l|}{$\begin{array}{l}\text { Directors' education and } \\
\quad \text { experience }\end{array}$} \\
\hline Graduate directors & $\%$ & & $71.4 \%$ & $78.5 \%$ & $23.7 \%$ & $0.0 \%$ & $100 \%$ \\
\hline $\begin{array}{l}\text { Directors with financial } \\
\text { experience }\end{array}$ & $\%$ & & $39.1 \%$ & $38.5 \%$ & $22.8 \%$ & $0.0 \%$ & $88.9 \%$ \\
\hline $\begin{array}{l}\text { Directors with international } \\
\text { experience }\end{array}$ & $\%$ & & $28.8 \%$ & $22.6 \%$ & $25.8 \%$ & $0.0 \%$ & $90.0 \%$ \\
\hline \multicolumn{8}{|l|}{ Boards' quality and skills } \\
\hline Education & score, scale $1-10$ & & 2.99 & 3.06 & 1.13 & 0.00 & 5.71 \\
\hline Board Experience & score, scale $1-10$ & & 4.14 & 4.19 & 1.00 & 1.62 & 5.93 \\
\hline Managerial Experience & score, scale $1-10$ & & 1.90 & 1.84 & 1.07 & 0.00 & 4.63 \\
\hline Overall quality and skills & $\begin{array}{c}\text { TOTAL score } \\
\text { scale } 1-30\end{array}$ & & 11.20 & 11.51 & 3.46 & 4.15 & 18.98 \\
\hline
\end{tabular}

the financial sector is around $39 \%$. The percentage of directors with international experience is lower (about 29\%). This confirms that the diversity in the demographic profiles of banks' boards is still low, compared to regulators' recommendations.

The average score for quality is 11.20 (on a scale from 1 to 30 points), with a minimum value of 4.15 and a maximum level of 18.98. Average score referred to managerial experience has the lowest result (1.9, on a scale from 1 to 10$)$ and a significant variability (minimum value equal to 0 , maximum value equal to 4.63 ). The largest contribution to total score is board experience (4.14 points, on a scale 1 to 10). This suggests that banks try to attract directors that have a significant previous experience in other boards, because of the high complexity and peculiar characteristics of the banking business.

The percentage of board members with financial expertize is, on average, lower for mutual banks (24\%), while it is near $71 \%$ for limited company banks (Table 7 ) and appears positively linked to bank size. As expected, it is higher for listed banks. 
Table 7 . The breakdown of the presence of board members with financial expertize.

\begin{tabular}{lc}
\hline Banks' categories & $\begin{array}{c}(\%) \text { of board members with } \\
\text { financial expertize }\end{array}$ \\
\hline Limited company banks & 71 \\
Cooperative banks & 62 \\
Mutual banks & 24 \\
Listed & 76 \\
Unlisted & 52 \\
Small & 15 \\
Medium & 64 \\
Large & 71 \\
Major & 80 \\
I size quartile & 38 \\
II size quartile & 61 \\
III size quartile & 71 \\
IV size quartile & 76 \\
\hline
\end{tabular}

These results are consistent with the need to have more qualified boards in larger and more complex organizations, e.g. in the case of public listed companies. Moreover, within the banking industry, listed banks also have to meet the standards required by the Corporate Governance Code for Listed Companies, that are more stringent than general governance rules applicable to all banks.

\subsection{Diversity}

Table 8 reports statistics for the diversity measures employed in the study: the different measures of diversity show the same levels in different breakdowns of our sample. They are complementary in analyzing diversity. Diversity indexes exhibit a link with quality: for all measures, the higher are the scores of diversity, the higher is quality.

The Blau indexes are very high for each feature for limited company banks and cooperative banks, especially with reference to education and managerial experience. This highlights a variety of profiles in these fields. Listed and unlisted banks do not show any particular difference, but for managerial experience and financial skills, unlisted banks have a lower index, i.e. lower variety or diversity.

When distinguishing between size category and size quartiles, results do not show strong differences in board experience. Smaller banks have a lower heterogeneity for education and managerial experience. Also, largest banks have a small level of the Blau index for education, although they have the highest for managerial experience. The heterogeneity of financial skills and competence has also been taken into account given the regulatory prescriptions.

With regard to financial skills, results on diversity appear to be less univocal. As expected, mutual banks, smaller banks and unlisted banks show lower levels of diversity. These figures, together with the presence of members with financial skills (Table 7), 
Table 8. Quality and diversity: averages for groups of banks.

\begin{tabular}{lrllllll}
\hline \multirow{2}{*}{ Groups of banks } & \multirow{2}{*}{$\begin{array}{c}\text { Quality } \\
\text { score }\end{array}$} & \multicolumn{7}{c}{ Diversity } \\
\cline { 3 - 8 } & & blau-e & blau-b & blau-m & blau-f & Jaccard & THS \\
\hline Full sample & 11.20 & 0.76 & 0.88 & 0.67 & 0.74 & 0.38 & 21.70 \\
Limited company banks & 12.46 & 0.81 & 0.88 & 0.73 & 0.82 & 0.38 & 22.22 \\
Cooperative banks & 11.80 & 0.82 & 0.89 & 0.72 & 0.84 & 0.38 & 21.75 \\
Mutual banks & 5.94 & 0.52 & 0.85 & 0.37 & 0.35 & 0.45 & 19.80 \\
Listed & 13.65 & 0.76 & 0.88 & 0.82 & 0.87 & 0.39 & 22.40 \\
Unlisted & 9.91 & 0.76 & 0.88 & 0.59 & 0.67 & 0.39 & 21.34 \\
Small & 6.16 & 0.54 & 0.84 & 0.36 & 0.34 & 0.45 & 19.13 \\
Medium & 10.96 & 0.81 & 0.89 & 0.64 & 0.78 & 0.38 & 21.97 \\
Large & 13.32 & 0.82 & 0.90 & 0.82 & 0.88 & 0.36 & 22.73 \\
Major & 14.72 & 0.69 & 0.83 & 0.91 & 0.87 & 0.40 & 21.86 \\
I size quartile & 8.48 & 0.68 & 0.87 & 0.50 & 0.55 & 0.41 & 20.13 \\
II size quartile & 10.12 & 0.83 & 0.90 & 0.60 & 0.75 & 0.37 & 23.21 \\
III size quartile & 12.09 & 0.81 & 0.88 & 0.70 & 0.82 & 0.38 & 22.21 \\
IV size quartile & 14.50 & 0.74 & 0.86 & 0.89 & 0.88 & 0.39 & 21.50 \\
\hline
\end{tabular}

Note: Quartiles are computed on total assets as at end of 2014.

highlight some criticalities if analyzed jointly with levels of financial expertize. This result is in accordance with the literature that points out that financial expertize of board members is important for banks (Aebi et al. 2012, Minton et al. 2014).

The average value for the Jaccard Index for the full sample is 0.38 , suggesting a quite strong diversity on the boards. Nevertheless, there are some differences among the groups of banks, with a lower degree of diversity in mutual banks and in major and small banks, as already found for the Blau index.

For major banks, this might be read together with the values of quality: it might suggest that major banks choose directors with the best profiles in each feature or, on the other way round, major banks are more attractive for skilled directors, hence limiting diversity but enhancing quality. In fact, as a consequence of the way indicators are built in this paper, the higher the presence of highly skilled directors, the higher the quality of the board, but the lower the diversity.

On the contrary, for mutual banks, limited heterogeneity is associated with a lower level of quality in boards. In this case, instead, a lower diversity seems to exist because of the presence of low-skilled directors. For these reasons, this group of banks is more exposed to risks in the failure of governance mechanisms.

The third diversity index, the THS, substantially confirms previous results, although differences among groups are more remarkable than those obtained with Blau and Jaccard Indexes. The average value is quite high (21.7), but diversity appears lower for mutual and smaller banks. The relationship between size and diversity provides the same results. Unlisted banks show lower diversity than listed ones. The evidence provided by Anderson et al. (2011) seems therefore confirmed: companies operating in more complex environments (such as banking and finance and different 


\section{R. Locatelli et al.}

sizes in banks) demand higher quality profiles with different skills, visions and problem-solving capacity, finally contributing to boards' heterogeneity.

Summarizing, mutual banks and smaller banks show a lower diversity and lower quality compared to other groups, which is consistent with the Italian banking experience.

\subsection{The relationship between quality and diversity in banking boards}

A first analysis of the averages of quality and diversity measures shows that if size increases (according to both regulatory and quartile categories), diversity and quality increase as well, but major banks present slightly lower diversity scores, together with the highest quality score (Table 8). This confirms our earlier assumption about better and more qualified profiles among directors of major banks, which might lower diversity, probably thanks to their attractiveness for better educated and more experienced directors, compared to other banks. In other words, evidence shown in Table 8 suggests that although diversity seems to be linked to a higher quality score in general, a more homogeneous board with skilled and qualified directors (hence with low diversity) might be the result of specific choices by the bank and of the ability to attract better directors, although with similar backgrounds. This might not be negative per se. The case for small banks with homogeneous boards, instead, is different and might highlight difficulties in attracting skilled directors. In this case, a low level of diversity can be detrimental to board performance.

Table 9 reports correlations between quality on one side and heterogeneity measures and some demographic characteristics on the other. The sign between quality and most of the diversity measures also suggests that when one increases, the other increases as well (more diversity). The correlation coefficients appear significant, especially for Blau-m, THS and Jaccard measures. For the latter measure, the sign is negative according to the fact that a Jaccard index equal to 1 means less diversity.

Table 9. Correlation matrix.

\begin{tabular}{|c|c|c|c|c|c|c|c|c|c|}
\hline & \multirow{3}{*}{$\begin{array}{c}\text { Quality } \\
\text { score }\end{array}$} & \multicolumn{8}{|c|}{ Diversity } \\
\hline & & \multicolumn{3}{|c|}{ Blau Indexes } & \multirow{2}{*}{$\begin{array}{c}\text { Jaccard } \\
\text { index }\end{array}$} & \multirow[t]{2}{*}{ THS } & \multicolumn{3}{|c|}{ Demographic profiles } \\
\hline & & Blau-e & Blau-b & Blau-m & & & cv age & Gender & Internat. \\
\hline Quality score & 1.0000 & & & & & & & & \\
\hline Blau-e & 0.3069 & 1.0000 & & & & & & & \\
\hline Blau-b & -0.0526 & 0.2906 & 1.0000 & & & & & & \\
\hline Blau-m & 0.7532 & 0.2533 & 0.1339 & 1.0000 & & & & & \\
\hline Jaccard & -0.2971 & -0.6962 & -0.4549 & -0.3979 & 1.0000 & & & & \\
\hline THS & 0.2029 & 0.5092 & 0.3275 & 0.2566 & -0.6261 & 1.0000 & & & \\
\hline cv age & 0.1120 & 0.0502 & 0.2085 & 0.0947 & -0.3155 & 0.4230 & 1.0000 & & \\
\hline Gender & 0.3112 & 0.1390 & 0.1364 & 0.3124 & -0.3631 & 0.4660 & 0.2724 & 1.0000 & \\
\hline International & 0.4140 & 0.1112 & 0.0433 & 0.4113 & -0.4311 & 0.2335 & 0.0060 & 0.0352 & 1.0000 \\
\hline
\end{tabular}

Note: Significant coefficients at $5 \%$ are reported in bold. 
Table 10. Regression analysis: Quality and diversity.

\begin{tabular}{|c|c|c|c|}
\hline & Reg1 & Reg2 & Reg3 \\
\hline \multicolumn{4}{|l|}{$\begin{array}{r}\text { Dependent variable: } \\
\text { quality score }\end{array}$} \\
\hline \multicolumn{4}{|l|}{ Independent variables: } \\
\hline \multicolumn{4}{|l|}{ Diversity Indexes } \\
\hline blau-e & $\begin{array}{l}\mathbf{0 . 5 3 1} * * * \\
(0.149)\end{array}$ & & \\
\hline blau-b & $\begin{array}{c}-0.165 \\
(0.291)\end{array}$ & & \\
\hline blau-m & $\begin{array}{l}\mathbf{0 . 6 9 0}^{* * *} \\
(0.123)\end{array}$ & & \\
\hline Jaccard & & $\begin{array}{l}-1.306 * * \\
(0.406)\end{array}$ & \\
\hline THS & & & $\begin{array}{c}0.009 \\
(0.010)\end{array}$ \\
\hline \multicolumn{4}{|l|}{ Other diversity features } \\
\hline cv age & $\begin{array}{l}-0.178 \\
(0.814)\end{array}$ & & \\
\hline gender & $\begin{array}{c}0.025 \\
(0.270)\end{array}$ & & \\
\hline international & $\begin{array}{c}0.073 \\
(0.123)\end{array}$ & & \\
\hline \multicolumn{4}{|l|}{ Control variables: } \\
\hline Bdsize & $\begin{array}{c}-\mathbf{0 . 0 1 8} * * \\
(0.007)\end{array}$ & $\begin{array}{c}-\mathbf{0 . 0 2 0} * * \\
(0.007)\end{array}$ & $\begin{array}{c}-\mathbf{0 . 0 1 7} * \\
(0.008)\end{array}$ \\
\hline Bksize & $\begin{array}{l}\mathbf{0 . 0 9 7} * * \\
(0.302)\end{array}$ & $\begin{array}{l}\text { 0.164*** } \\
(0.019)\end{array}$ & $\begin{array}{l}\text { 0.160*** } \\
(0.247)\end{array}$ \\
\hline Constant & $\begin{array}{c}0.279 \\
(0.610)\end{array}$ & $\begin{array}{c}0.393 \\
(0.343)\end{array}$ & $\begin{array}{c}-0.264 \\
(0.415)\end{array}$ \\
\hline$N$ & 58 & 58 & 58 \\
\hline Pseudo $R^{2}$ & 0.154 & 0.115 & 0.102 \\
\hline $\mathrm{Chi}^{2}$ (degrees of freedom) & $191.967(8)$ & $87.582(3)$ & $48.594(3)$ \\
\hline
\end{tabular}

Notes: $\left({ }^{\dagger}\right)$ significant at $10 \% ;(*)$ significant at $5 \% ;(* *)$ significant at $1 \% ;(* * *)$ significant at $0.1 \%$. Robust standard errors are indicated in parentheses.

Interestingly, diversity also appears negatively, although weakly $(-0.14)$, correlated with board size. This might suggest that diversity is not necessarily achieved by increasing the number of directors and confirms the appropriateness of regulatory rules that prescribe a maximum number of directors.

Table 10 reports results on the relationship between quality and diversity. ${ }^{\mathrm{q}} \mathrm{We}$ specified different regression models: specifications of the model in Eq. (3.1) show that different measures of diversity (on a single variable, i.e. gender, or "synthetic", i.e. Blau Indexes, Jaccard Index and THS) have different signs and impacts on quality score. Since Jaccard Index and THS are built on the same variables defining the Blau Indexes and included in Reg1, these are tested in isolation in Reg2 and Reg3.

qFor the sake of synthesis, we report only the most relevant specifications of the model. 


\section{R. Locatelli et al.}

The first regression shows that among the Blau diversity measures, Blau-e (education) and Blau-m (managerial experience) show strong statistical significance and positive sign, suggesting that the higher the degree of diversity in these two profiles, the higher the quality is. This suggests that diversity contributes to quality and that uniform boards instead are, on average, less qualified. This supports Hypothesis 1. Diversity could thus reward very qualified boards composed of highly skilled directors.

The diversity in age, proxied by the variable "cv age" is negative, but not significant: evidence fails to support Hypothesis 2. Differently, the presence of female directors and members with international experience contribute positively to quality score. Nevertheless, the coefficients do not have statistical significance. This does not allow us to confirm Hypotheses 3 and 4.

Control variables (bank size and board size) are both significant. The first (Bksize) is positive, suggesting that larger banks might be more attractive to more qualified directors. The second (Bdsize) is negative and highlights again that increasing board size is not a suitable strategy to increase quality.

Reg2 shows that the Jaccard score is significant and negative, suggesting that the higher the diversity (i.e. the lower the Jaccard Index), the higher the quality score is for the board. On the contrary, THS in Reg3 appears not statistically significant and small in value. In both regressions (Reg2 and Reg3), the control variables keep their sign and significance.

Table 11 reports regression results when controlling for financial expertize.

Table 11. Regression analysis: Quality, financial expertize and diversity.

\begin{tabular}{|c|c|c|}
\hline & Reg1 & Reg2 \\
\hline \multicolumn{3}{|l|}{$\begin{array}{l}\text { Dependent variable: } \\
\text { quality score }\end{array}$} \\
\hline \multicolumn{3}{|l|}{ Independent variables: } \\
\hline Jaccard & $\begin{array}{l}-\mathbf{1 . 2 1 7} * * * \\
(0.283)\end{array}$ & \\
\hline THS & & $\begin{array}{c}0.001 \\
(0.006)\end{array}$ \\
\hline Financial expertize & $\begin{array}{l}\mathbf{0 . 8 6 3} * * * \\
(0.106)\end{array}$ & $\begin{array}{l}\mathbf{0 . 8 7 6}^{* * * *} \\
(0.129)\end{array}$ \\
\hline \multicolumn{3}{|l|}{ Control variables } \\
\hline Bdsize & $\begin{array}{c}-\mathbf{0 . 0 1 3} * * \\
(0.005)\end{array}$ & $\begin{array}{r}-\mathbf{0 . 0 0 9}^{\dagger} \\
(0.006)\end{array}$ \\
\hline Bksize & $\begin{array}{l}\mathbf{0 . 0 8 1}^{* * *} \\
(0.017)\end{array}$ & $\begin{array}{l}\mathbf{0 . 0 7 6}^{* *} \\
(0.017)\end{array}$ \\
\hline Constant & $\begin{array}{l}\mathbf{1 . 1 2 6}^{* * *} \\
(0.231)\end{array}$ & $\begin{array}{c}\mathbf{0 . 6 6 0}^{*} \\
(0.308)\end{array}$ \\
\hline$N$ & 58 & 58 \\
\hline Pseudo $R^{2}$ & 0.171 & 0.160 \\
\hline $\mathrm{Chi}^{2}$ (degrees of freedom) & $401.04(4)$ & $180.77(4)$ \\
\hline
\end{tabular}

Notes: $\left(^{\dagger}\right)$ significant at $10 \% ;(*)$ significant at $5 \% ;(* *)$ significant at $1 \%$; $(* * *)$ significant at $0.1 \%$. Robust standard errors are indicated in parentheses. 
As we expected, more widespread financial expertize and education within banking boards have a positive impact on boards' quality score. Moreover, Jaccard Index remains significant and with a positive sign. Control variables both remain significant: in particular, board size has a negative sign, suggesting that the board dimension is negatively related with quality score. Our results seem to confirm the appropriateness of the more recent regulatory approach, which stresses the relevance of financial culture and expertize of banks' board members. Furthermore, we find consistency with data reported in Table 7, which shows that financial skills are more diffused in bigger banks, which also show higher quality scores.

\section{Conclusions}

This paper fits into the wide literature on the boards of directors in banks but takes a different and innovative perspective by analyzing diversity and quality together, considering the various directors' profiles. Synthetic quality and diversity measures are built consistently with regulatory rules on a hand-collected dataset containing the characteristics of 700 directors of 54 Italian banks, representing $86 \%$ of total assets of the Italian banking system as at 2014. Besides, it makes an original contribution by analyzing the relationship between quality and different measures of diversity to test if a high level of diversity is consistent with high quality. In other words, do banks select "diverse" directors that overall strengthen the board competence?

Results show that diversity seems to be higher for larger banks, except for major ones. These might have more attractive power to the well-educated and experienced directors. On the one hand, this power contributes to quality, but on the other, it may result in uniform types of directors in the board, without implying a negative effect on the board competence level. On the contrary, boards of directors in mutual banks appear the least diversified and also the ones with the lowest quality score, meaning that they are constituted by low skilled and similar directors. This might have imposed to mutual banks a review of their boards as the new regulatory provisions were coming into force.

Empirical evidence additionally shows a positive relationship between each of the three measures of diversity (Blau Index, Jaccard Index and THS) and quality (measured as educational level and degree of experience of directors). Evidence and discussion of results highlight that comprehensive measures (such as Jaccard and THS) would be more suitable to explain diversity according to the general notion used by regulators, but more traditional measures (such as Blau index) can provide more detailed insight on the elements that contribute to diversity. It follows that the measures of diversity should be used jointly.

This study provides also some hints for further research. The role of diversity in determining quality should be better investigated because boards of directors are likely to change when new regulations come into effect. This would require tracking over time the evolution of the composition of boards of directors in the next years to 


\section{R. Locatelli et al.}

evaluate the choices of banks and introduce a dynamic component in the analysis would enrich the research and policy debate.

Additionally, it would be interesting to extend the research to other countries, to perform an international comparison, with a special focus on the European Banking Union, in which regulation on bank corporate governance is growing homogeneously.

\section{Appendix A. Results of Principal Component Analysis}

Due to the high level of heterogeneity showed by descriptive analysis, we applied Principal Component Analysis (PCA) in order to detect, on the one hand, which profiles most contribute to the overall score (quality) of each board, and, on the other, which are the main characteristics that contribute significantly to differentiate boards among them. Variables and individual scores used in PCA are referred to education and background, board experience and managerial experience ("practical competencies"). They represent the three components of our analysis. Results are summarized in Table A.1 and in Fig. A.1.

Results confirm that all identified profiles contribute, almost equally, to the overall score and to the understanding of differences among boards (Table A.1) and hence appear important to appreciate qualities and skills of board members, as required by regulation. Comp 1 and Comp 2 - as linear combination of the original variables - help to explain more than $89 \%$ of sample variability (see Table 5 which shows the average, minimum and maximum values of total assets, as well as the average numbers of board members of the sample banks). Therefore, they are highly significant in the analysis of the phenomenon. In other words, boards differ among them mainly on the basis of two out of three components. The sign of each coefficient suggests, in comparative terms, the impact of each component in boards differentiation.

Figure A.1 summarizes differences among boards, clustered by legal form, bank size class and listing. Each pair represented in the graph is a board, located in the area according to Comp 1 and Comp 2.

Table A.1. The results of PCA on directors' level of education and skills.

\begin{tabular}{|c|c|c|c|c|}
\hline \multicolumn{2}{|c|}{ Principal components/correlation } & \multicolumn{2}{|c|}{$\begin{array}{l}\text { Number of obs } \\
\text { Number of components }\end{array}$} & \multirow{2}{*}{$\begin{array}{c}58 \\
3 \\
\text { Cumulative }\end{array}$} \\
\hline Component & Eigenvalue & Difference & Proportion & \\
\hline Comp 1 & 2.0723 & 1.4521 & 0.6908 & 0.6908 \\
\hline Comp 2 & 0.6202 & 0.3128 & 0.2067 & 0.8975 \\
\hline Comp 3 & 0.3075 & 0.0000 & 0.1025 & 1.0000 \\
\hline Variable & Comp 1 & Comp 2 & & \\
\hline Education & 0.6187 & -0.2329 & & \\
\hline Board experience & 0.5172 & 0.8397 & & \\
\hline Managerial experience & 0.5914 & -0.4906 & & \\
\hline
\end{tabular}



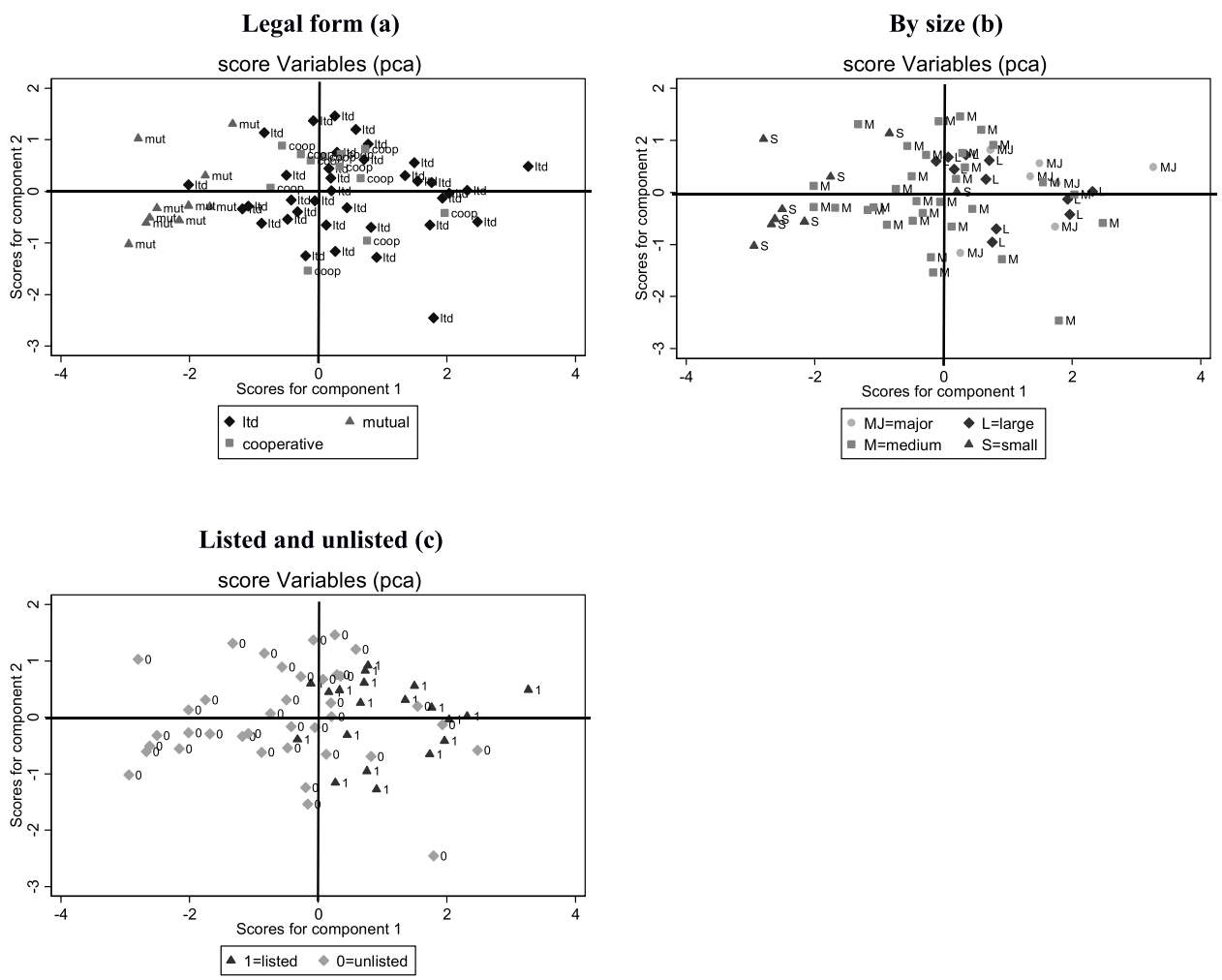

Fig. A.1. The representation of PCA by banks' clusters.

Boards placed to the right of zero by Comp 1 ( $X$-axis) have, on average, directors with a higher education score, as well as greater board and managerial experience. Vice versa, with reference to Comp 2 ( $Y$-axis), the boards placed on the top (i.e. above 0) are characterized on average by directors with a higher level of board experience, but a lower education score and a lower score for managerial experience. The weights of these variables have a negative sign. Moreover, the comparison between two boards with the same score of Comp 1 ( $X$-axis) is mainly determined by directors' board experience, i.e. the variable with the highest coefficient — in absolute value - for Comp 2). With regard to Comp 1, all mutual banks are placed at the left of zero. Within their boardrooms, only in a few cases directors have significant board experience in other boards (III quadrant, positive coefficient for Comp 2) and have a lower level of education and also of managerial experience (IV quadrant, negative coefficient for Comp 2). Vice versa, the majority of limited company banks and a relevant share of cooperative banks have positive coefficients for Comp 1. Their boardrooms are not significantly different in terms of boards' qualification. With reference to bank size, all small banks (except one) are on the left by Comp 1, while major banks are placed to the right (Fig. A.1, panel b). The distribution of the other banks is quite widespread. This seems to suggest that 


\section{R. Locatelli et al.}

board qualification is higher for larger and more complex banks. A possible explanation can be related to the greater attractiveness of such banks to best and highest skilled directors. Moreover, the smallest banks suffer of lower qualification and might have needed to attract more qualified members in the latest years to meet the forthcoming regulatory provisions.

The boards of listed banks are almost all (but two exceptions) on the right side by Comp 1: board members have a higher level (and corresponding score) in education, as well as in board and managerial experience. We may probably conclude that listed banks have a greater attractiveness for more qualified profiles. Moreover, it is worth mentioning that Italian companies listed on Italian Stock Exchange apply a selfregulation Code and regulation specifically aimed at listed companies, which resulted in a board qualification process board that anticipated banking regulation. Finally, it has to be considered that there are also some unlisted banks whose board members are highly qualified and skilled.

The framework depicted with PCA does not show any strong aggregation of clusters of banks in a precise point or area. As a consequence, we may conclude that bank size and legal form do not uniquely define the board qualification. Nevertheless, the majority of boards of the largest banks and listed ones are, on average, more skilled and qualified: board members have a higher level of education and experience, both for attractiveness and regulatory constraints.

\section{Acknowledgments}

The Authors would like to thank two anonymous referees and the Editor for their valuable and precious comments on the paper. The Authors would like to thank Prof. Francesco Cesarini, Prof. Paola Vezzani, Prof. Raffaello Seri and participants of ADEIMF 2016 Summer Conference, for their useful comments on the preliminary versions of this paper.

\section{References}

R. B. Adams \& D. Ferreira (2009) Women in the boardroom and their impact on governance and performance, Journal of Financial Economics 94 (2), 291-309.

R. B. Adams, A. C. Akyol \& P. Verwijmeren (2018) Director skill sets, Journal of Financial Economics, forthcoming, https://doi.org/10.1016/j.jineco.2018.04.010.

R. B. Adams, B. E. Hermalin \& M. S. Weisbach (2010) The role of boards of directors in corporate governance: A conceptual framework and survey, Journal of Economic Literature 48 (1), 58-107.

V. Aebi, G. Sabato \& M. Schmid (2012) Risk management, corporate governance, and bank performance in the financial crisis, Journal of Banking $\mathscr{E}$ Finance 36 (12), 3213-3226.

A. Agrawal \& C. R. Knoeber (1996) Firm performance and mechanisms to control agency problems between managers and shareholders, Journal of Financial and Quantitative Analysis 31 (3), 377-397.

R. C. Anderson, D. M. Reeb, A. Upadhyay \& W. Zhao (2011) The economics of director heterogeneity, Financial Management Spring, 5-38. 
J. Armour, D. Awrey, P. L. Davies, L. Enriques, C. Mayer \& J. Payne (2016) Bank Governance, ECGI Working Paper Series in Law, Working Paper N ${ }^{\circ}$. 316/2016, June 2016, Available at http://ssrn.com/abstract $=2793112$.

F. Arnaboldi, B. Casu, E. Kalotychou \& A. Sarkisyan (2018). The performance effects of board heterogeneity: What works for EU banks? The European Journal of Finance, forthcoming, https://doi.org/10.1080/1351847X.2018.1479719.

Bank of Italy (2006) Circular no. 263 of 27 December 2006, New regulations for the prudential supervision of banks.

Bank of Italy (2008) Disposizioni di vigilanza in materia di organizzazione e governo societario delle banche.

K. A. Bantel \& S. E. Jackson (1989) Top management and innovations in banking: Does the composition of the top team make a difference? Strategic Management Journal 10 (SI1), 107-124.

Basel Committee for Banking Supervision (2015) Corporate Governance Principles for Banks, $8^{\text {th }}$ July.

B. D. Baysinger \& H. N. Butler (1985) Corporate governance and the board of directors: Performance effects of changes in board composition, Journal of Law, Economics, 83 Organization 1 (1), 101-124.

S. Bear, N. Rahman \& C. Post (2010) The impact of board diversity and gender composition on corporate social responsibility and firm reputation, Journal of Business Ethics 97 (2), 207-221.

A. Beltratti \& R. M. Stulz (2012) The credit crisis around the globe: Why did some banks perform better? Journal of Financial Economics 105 (1), 1-17.

A. N. Berger, B. Imbierowicz \& C. Rauch (2016) The roles of corporate governance in bank failures during the recent financial crisis, Journal of Money, Credit and Banking 48 (4), $729-770$.

S. Bhagat \& B. Black (2002) The non-correlation between board independence and long term firm performance, Journal of Corporation Law 27, 231-274.

T. H. Blau (1977) Quality of life, social indicators, and criteria of change, Professional Psychology: Research and Practice 8 (4), 464-473.

Ø. Bøhren \& R. Ø. Strøm (2010) Governance and politics: Regulating independence and diversity in the board room, Journal of Business Finance and Accounting 37 (9-10), 1281-1308.

J. A. Brickley, J. L. Coles \& R. L. Terry (1994) Outside directors and the adoption of poison pills, Journal of Financial Economics 35 (3), 371-390.

R. J. Burke (1997) Women on corporate boards of directors: A needed resource, Journal of Business Ethics 16 (9), 909-915.

K. Campbell \& A. Mínguez-Vera (2008) Gender diversity in the boardroom and firm financial performance, Journal of Business Ethics 83 (3), 435-451.

A. Carretta \& P. Schwizer (2015) Governance 2.0. Stili di vigilanza, buona governance e cultura dei rischi per la finanza di domani, Bancaria Editrice, Rome.

S. Caselli (2010) Governance and strategy within the financial system: Tradition and innovation, Journal of Management and Governance, 14 (3), 241-271.

A. Chao, R. L. Chazdon, R. K. Colwell \& T. J. Shen (2005) A new statistical approach for assessing similarity of species composition with incidence and abundance data, Ecology Letters 8 (2), 148-159.

J. L. Coles, N. D. Daniel \& L. Naveen (2008) Boards: Does one size fit all? Journal of Financial Economics 87 (2), 329-356.

J. L. Coles, N. D. Daniel \& L. Naveen (2015) Director overlap: Groupthink versus teamwork, University of Utah, Working Paper. 
M. M. Cornett, J. J. McNutt \& H. Tehranian (2009) Corporate governance and earnings management at large U.S. bank holding companies, Journal of Corporate Finance 15 (4), 412-430.

V. Cuñat \& L. Garicano (2010) Did good cajas extend bad loans? Governance, human capital and loan portfolios, Working papers, 2010-08, FEDEA.

D. R. Dalton, C. M. Daily, J. L. Johnson \& A. E. Ellstrand (1999) Number of directors and financial performance: A meta-analysis, Academy of Management Journal 42 (6), $674-686$.

J. de Haan \& R. Vlahu (2016) Corporate governance of banks: A survey, Journal of Economic Surveys 30 (2), 228-277, doi: 10.1111/joes.12101.

S. Del Prete \& M. L. Stefani (2015) Women as 'gold dust': Gender diversity in top boards and the performance of Italian banks, Bank of Italy Working Papers, 1014.

EBA (2016) Consultation Paper - Draft Guidelines on internal governance Guidelines (EBA/CP/2016/16), 28/10/2016.

ECB (2017) Guide to Fit and Proper Assessments, May 2017, Available at https://www. bankingsupervision.europa.eu/ecb/pub/pdf/ssm.fap_guide_201705.en.pdf.

ESMA - EBA (2016) Consultation Paper - Joint ESMA and EBA Guidelines on the assessment of the suitability of members of the management body and key function holders under Directive 2013/36/EU and Directive 2014/65/EU (EBA/CP/2016/17), $28 / 10 / 2016$.

O. Faleye, R. Hoitash \& U. Hoitash (2017) Industry expertise on corporate boards, Review of Quantitative Finance and Accounting, doi: 10.1007/s11156-017-0635-z.

E. F. Fama \& M. C. Jensen (1983) Separation of ownership and control, Journal of Law and Economics 26 (2), 301-325.

A. Ferreira (2010) Board Diversity, Paragraph 12 in. In Corporate Governance: A Synthesis of Theory, Research, and Practice (R. Anderson \& H. K. Baker eds.), 225-242. John Wiley \& Sons.

C. Frigeni (2016) La governance bancaria come risk governance: l'evoluzione della regolamentazione internazionale ed europea dopo la crisi, Osservatorio Monetario 1, 19-33.

D. P. Forbes \& F. J. Milliken (1999) Cognition and corporate governance: Understanding boards of directors as strategic decision-making groups, Academy of Management Review 24 (3), 489-505.

P. Hardwick, M. Adams \& H. Zou (2011) Board characteristics and profit efficiency in the United Kingdom life insurance industry, Journal of Business Finance $\mathcal{E}$ Accounting 38 (7-8), 987-1015.

M. Harris \& A. Raviv (2006) A theory of board control and size, The Review of Financial Studies 21 (4), 1797-1832.

I. C. Harris \& K. Shimizu (2004) Too busy to serve? An examination of the influence of overboarded directors, Journal of Management Studies 41 (5), 775-798.

D. A. Harrison \& K. J. Klein (2007) What's the difference? Diversity constructs as separation, variety, or disparity in organizations, Academy of Management Review 32 (4), $1199-1228$.

H. Hau \& M. Thum (2009) Subprime crisis and board (in-)competence: Private versus public banks in Germany, Economic Policy 24 (60), 701-752.

B. E. Hermalin \& M. S. Weisbach (1991) The effects of board composition and direct incentives on firm performance, Financial Management 20 (4), 101-112.

K. J. Hopt (2013) Corporate governance of banks and other financial institutions after the financial crisis, Journal of Corporate Law Studies 13 (Part 2), 219-253.

P. Jaccard (1901) Étude comparative de la distribution florale dans une portion des Alpes et des Jura, Bulletin de la Société Vaudoise des Sciences Naturelles 37, 547-579. 
N. Jassaud (2014) Reforming the corporate governance of Italian Banks, IMF Working Papers, 14/181.

M. Jensen (1993) The modern industrial revolution, exit, and the failure of internal control systems, The Journal of Finance 48, 831-880.

K. John, S. De Masi \& A. Paci (2016) Corporate governance in banks, Corporate Governance: An International Review 24 (3), 303-321.

A. Klein (1998) Firm performance and board committee structure, The Journal of Law 83 Economics 41 (1), 275-304.

L. Laeven (2013) Corporate governance: What's special about banks? Annual Review of Financial Economics 5, 63-92.

R. Levine (2004) The corporate governance of banks: A concise discussion of concepts and evidence, World Bank Research, Washington DC, Working paper no. 3404.

M. Lipton \& J. W. Lorsch (1992) A modest proposal for improved corporate governance, The Business Lawyer 48 (1), 59-77.

R. Locatelli, C. Schena, A. Tanda \& A. Uselli (2018) La relazione tra diversità e competenza dei board e performance delle banche, Bancaria 6, 44-59.

J. R. Macey \& M. O'Hara (2003) The corporate governance of banks, Economic Policy Review $9(1), 91-108$.

S. Machold, M. Huse, A. Minichilli \& M. Nordqvist (2011) Board leadership and strategy involvement in small firms: A team production approach, Corporate Governance: An International Review 19 (4), 368-383.

R. W. Masulis, C. Wang \& F. Xie (2012) Globalizing the boardroom - The effects of foreign directors on corporate governance and firm performance, Journal of Accounting and Economics 53 (3), 527-554.

H. Mehran, A. Morrison \& J. Shapiro (2011) Corporate governance and banks: What have we learned from the financial crisis? Federal Reserve Bank of New York Staff Reports No. 502.

T. Miller \& M. Del Carmen Triana (2009) Demographic diversity in the boardroom: Mediators of the board diversity-firm performance relationship, Journal of Management Studies 46 (5), 755-786.

B. A. Minton, J. P. A. Taillard \& R. G. Williamson (2014) Financial expertise of the board, risk taking, and performance: Evidence from bank holding companies, Journal of Financial and Quantitative Analysis 49 (2), 351-380.

C. S. Mishra \& J. F. Nielsen (2000) Board independence and compensation policies in large bank holding companies, Financial Management 29 (3), 51-70.

P. O. Mülbert (2009) Corporate governance of banks, European Business Organization Law Review 10 (3), 411-436.

A. Nobi, S. Lee, D. H. Kim \& J. W. Lee (2014) Correlation and network topologies in global and local stock indices, Physics Letters A 378 (34), 2482-2489.

OECD (2015) G20/OECD Principles of Corporate Governance, OECD Report to G20 Finance Ministers and Central Bank Governors, September, https://www.oecd.org/daf/ ca/Corporate-Governance-Principles-ENG.pdf.

S. Pathan (2009) Strong boards, CEO power and bank risk-taking, Journal of Banking and Finance 33 (7), 1340-1350.

G. T. Payne, G. S. Benson \& D. L. Finegold (2009) Corporate board attributes, team effectiveness and financial performance, Journal of Management Studies 46 (4), 704-731.

A. Pugliese, P. J. Bezemer, A. Zattoni, M. Huse, F. A. Van den Bosch \& H. W. Volberda (2009) Boards of directors' contribution to strategy: A literature review and research agenda, Corporate Governance: An International Review 17 (3), 292-306. 


\section{R. Locatelli et al.}

O. C. Richard (2000) Racial diversity, business strategy, and firm performance: A resourcebased view, Academy of Management Journal 43 (2), 164-177.

P. Schwizer (2017) Gli esami non finiscono mai. Il nuovo Fit \& Proper Test per gli amministratori bancari alla prova della fattibilità, Bancaria $3,2-12$.

C. E. Shalley (1991) Effects of productivity goals, creativity goals, and personal discretion on individual creativity, Journal of Applied Psychology 76 (2), 179.

G. Shergill (2001) Does industry matter? The evidence from New Zealand study, Working Paper No. 03.06, Department of Commerce, Massey University Albany Campus, Auckland.

A. Solanas, R. M. Selvam, J. Navaro \& D. Leiva (2012) Some common indices of group diversity: Upper boundaries, Psychological Reports 111 (3), 777-796.

J. Sonnenfeld (2002) What makes great boards great, Harvard Business Review, September.

A. Srivastav \& J. Hagendorff (2016) Corporate governance and bank risk-taking, Corporate Governance: An International Review 24 (3), 334-345.

C. Y. Tsai \& C. C. Chiu (2004) A purchase-based market segmentation methodology, Expert Systems with Applications 27 (2), 265-276.

N. Van der Walt \& C. Ingley (2003) Board dinamics and the influence of professional background, gender and ethnic diversity of directors, Corporate Governance: An International Review 11 (3), 404-413.

F. Van Meyerinck, D. Oesch \& M. Schmid (2016) Is director industry experience valuable? Financial Management 45 (1), 207-237.

N. Van der Walt, C. Ingley, G. S. Shergill \& A. Townsend (2006) Board configuration: Are diverse boards better boards? Corporate Governance: The International Journal of Business in Society 6 (2), 129-147.

M. S. Weisbach (1988) Outside directors and CEO turnover, Journal of Financial Economics $20(\mathrm{C}), 431-460$.

D. Yermack (1996) Higher market valuation of companies with a small board of directors, Journal of Financial Economics 40 (2), 185-211.

D. Yermack (2006) Board members and company value, Financial Markets and Portfolio Management 20 (1), 33-47. 